\title{
CHOCOLATE MAKING WITH MINT (MENTHA $X$ PIPERITE) AND BLUEBERRY (Vaccinium sp.)
}

Elaboração de chocolates com adição de menta (Mentha x piperite) e mirtilo (Vaccinium sp.)

Giulia Rodrigues Bareta ${ }^{1}$, Greice Kelly Alves ${ }^{1}$, Bruno Fischer ${ }^{1}$, Eunice Valduga ${ }^{1}$, Geciane Toniazzo Backes $^{1}$, Rogério Luis Cansian ${ }^{1}$, Rosicler Colet ${ }^{1}$, Ilizandra Aparecida Fernandes ${ }^{1}$, Jamile Zeni1 ${ }^{*}$

${ }^{1}$ Department of Food Engineering, URI - Erechim, RS. E-mail: jamilezeni@uricer.edu.br (J. Zeni)

Data do recebimento: 31/03/2020 - Data do aceite: 01/08/2020

Resumo: Alimentos com propriedades funcionais despertaram o interesse dos consumidores pelos benefícios à saúde. Neste trabalho, a menta e o mirtilo foram escolhidos para adição nos chocolates, como fonte de compostos bioativos, por apresentarem propriedades funcionais. O objetivo deste trabalho foi avaliar as características físico-químicas (cor, umidade, atividade de água, acidez, viscosidade e $\mathrm{pH}$ ) e propriedades antioxidantes pelo método DPPH de chocolates amargos, brancos e ao leite, adicionados de casca e sementes de mirtilo e extrato hidroalcoólico de menta nas concentrações de 3 e $0.3 \%$, respectivamente. Em relação aos parâmetros de cor, as maiores diferenças foram observadas nas amostras contendo mirtilo. O teor de umidade e a viscosidade dos chocolates tendem a diminuir com a presença da menta e do mirtilo, enquanto a atividade de água tende a aumentar para os chocolates amargo e branco. $\mathrm{O}$ pH do chocolate ao leite diminuiu com a adição da menta e do mirtilo, enquanto a acidez do chocolate ao leite aumentou. Já para o amargo diminuiu e para o branco não alterou. Em relação à atividade antioxidante, as concentrações utilizadas de mirtilo e menta não foram eficazes no aumento desta propriedade. Portanto, concentrações mais altas são necessárias para melhorar as propriedades funcionais dos chocolates.

Palavras-chave: Alimentos funcionais. Aplicação em alimentos. Compostos fenólicos. Coproduto.

Abstract: Food with functional properties have sparked consumer interest due to health benefits. In this work, mint and blueberry were chosen to be added to chocolate as a source of bioactive compounds because they have functional 
properties. The aim of this study was to evaluate the physical-chemical characteristics (color, moisture content, water activity, acidity, viscosity and $\mathrm{pH}$ ) and antioxidant properties by the DPPH method of bitter, white and milk chocolate, added with blueberry peel and seeds and hydro-alcoholic mint extract in concentrations of 3 and $0.3 \%$, respectively. Regarding color parameters, the greatest differences were observed in samples containing blueberry. The moisture content and viscosity of chocolate tend to decrease with the presence of mint and blueberry, while water activity tends to increase for bitter and white chocolate. The $\mathrm{pH}$ of milk chocolate decreased with the addition of mint and blueberry, while the acidity of milk chocolate increased, as long as for bitter chocolate it decreased and for white chocolate it did not change. Regarding the antioxidant activity, the concentrations of blueberry and mint used were not effective in increasing this property. Therefore, higher concentrations are needed to improve chocolate functional properties.

Keywords: Functional food. Application in food. Phenolic compounds. Coproduct.

\section{Introduction}

Chocolate is a product obtained from the processing of cocoa (Theobroma cacao L.), and the main steps of this process are fermentation, drying and roasting. A complex mixture of compounds is responsible for the flavor of chocolate, which are appreciated due to their unique sensory characteristics. Among the compounds related to the sensory and functional quality of cocoa products are phenolic and alkaloids (MUDENUTI et al., 2018; VANDERSCHUEREN et al., 2019).

Some beneficial health properties are attributed to the phenolic compounds present in cocoa products, such as the antioxidant activity already reported in the literature, which provides positive effects like LDL cholesterol reduction, anti-inflammatory activity and the prevention of some chronic diseases (ANDÚJAR et al., 2012). Naturally, cocoa beans are rich in phenolic compounds, however, during the making of chocolate the content of these bioactive compounds decreases, especially in fermentation and roasting (MUHAMMAD et al., 2018).

Antioxidant compounds are necessary to control reactive oxygen species and other free radicals that are harmful to human health or capable of promoting food oxidative degradation. Compounds with antioxidant properties, mainly the phenolic class (flavonoids, anthocyanins), occur naturally in fruit, vegetables and teas, providing an alternative to the food industries to use synthetic antioxidants (MOO-HUCHIN et al., 2015).

Among the various known mint species, peppermint (Mentha x piperite), a hybrid from the species M. spicata and M. aquatic, is an important source of essential oil with large amounts of menthol and mentone monoterpenes, of great value and commercial importance (MACHIANI et al., 2018). In addition to the essential oil, other compounds such as phenolic can be found in peppermint leaves. These compounds have beneficial biological properties such as antioxidant, 
anti-diabetics and antitumor activity. One of the common applications of peppermint is in the production of toothpaste, chewing gums, mouthwashes and beverages due to their refreshing sensory characteristics (ÇAM et al., 2018).

Blueberry (Vaccinium myrtillus L.) is a species that belongs to the Eriaceae family, popular in northern Europe and North America. Blueberry fruit, popular for their bittersweet and balanced taste, is usually consumed as fresh fruit, or jam, syrup and juice when processed. Blueberries have great nutritional value, mainly due to the high amount of bioactive compounds such as anthocyanins, flavonoids and tocopherols, and these compounds are associated with multiple biological effects (MIKULICPETKOVSEK et al., 2015; GUSTINELLI et al., 2018).

The ingestion of natural antioxidants, such as polyphenols, carotenoids and vitamins, may help in degenerative diseases prevention including cardiovascular disorders, oxidative stress and inflammatory responses (BABOVA et al., 2016). The addition of bioactive compounds in food, such as biscuits (BAJAJ; UROOJ; PRABHASANJAR, 2016; DORDONI et al., 2019; PAPILLO et al., 2019), extruded snacks (JOZINOVIC et al., 2018), dairy products (JASTER et al., 2018; KWON et al. 2019; SARAIVA et al., 2019), meat products (MADANE et al., 2019; SHAHAMIRIAN et al., 2019) and chocolate (JAHANGIR et al., 2018; LONCAREVIC et al., 2018; LONCAREVIC et al., 2019), aiming to add functional properties and health benefits to consumers, has been the subject of several researches lately.

The objective of this study was to evaluate the physical-chemical and antioxidant characteristics of milk, bitter and white chocolate, with the addition of hydroalcoholic mint extract, blueberry peel and seed.

\section{Material and methods}

\section{Blueberry By-product and Mint Extract}

The blueberry by-product generated after the extraction of the juice, consisting of peel and seed, was donated by an organic industry from Rio Grande do Sul. The blueberry by-product was dehydrated at $60{ }^{\circ} \mathrm{C}$ for 24 $\mathrm{h}$, crushed in an industrial grain mill, and silved using Tyler sieves (32 Ty - $500 \mu \mathrm{m}$ ) to standardize the granulometry.

The mint used was Mentha $x$ piperite, donated by a herb industry from Rio Grande do Sul. The sample that was already dehydrated was ground in a knife mill with a sieve diameter of $850 \mu \mathrm{m}$ (20 Mesh). Cold maceration extraction followed the methodology of Ramar et al. (2015) with adaptations, where $25 \mathrm{~g}$ of plant material were infused into 250 $\mathrm{mL}$ of solvent $(1: 10)$ for $72 \mathrm{~h}$ remaining at a temperature of $7 \pm 1{ }^{\circ} \mathrm{C}$. The solvent used was a $70 \%$ hidro-alcoholic solution, defined from the study by Fischer et al. (2020) as the best concentration. The ethanol extracts obtained were filtered on qualitative filter paper (JPROLAB) and kept for 15 days in a vacuum oven (Quimis) at $60{ }^{\circ} \mathrm{C}$ for solvent evaporation. Finally the extracts were dried up in a circulating oven (Marconi) at $40{ }^{\circ} \mathrm{C}$ for $24 \mathrm{~h}$ and stored in amber bottles.

\section{Chocolate Formulation}

The kinds of chocolate used in this study were bitter (Nestlé), white (Garoto) and milk (Nestlé) chocolate, which were bought in the local market in packages of $1 \mathrm{~kg}$ each. In order to prepare the chocolate to receive the blueberry and mint extract flavor, first the chocolate was chopped, then it was melted, in portions of $100 \mathrm{~g}$, in a glass bowl in the microwave with a maximum frequency of approximately 2 min, with intervals of 30 
s for homogenization. In the sequence, the chocolate went through the tempering process until the dough reached $28^{\circ} \mathrm{C}$, and then the mint and the blueberry were added to it in concentrations of $0.3 \%$ and $3.0 \%(\mathrm{w} / \mathrm{w})$, respectively. The concentrations were defined according to Batiston et al. (2016), Carlsen et al. (2003), Fischer et al. (2020) studies and also by preliminary tests. After the homogenization of the ingredients, the samples were packaged in plastic moulds and stored at -20 ${ }^{\circ} \mathrm{C}$ for cooling. After cooling, the samples, approximately $25 \mathrm{~g}$, were removed from the plastic moulds and stored in an open space, with moisture and light, until the analysis was performed.

\section{Physical and Chemical Analysis}

The physical and chemical analyzes performed were color, moisture, water activity, acidity, viscosity and $\mathrm{pH}$. In addition, the antioxidant activities and the total phenolic content of the manufactured products were determined. Commercial chocolate without the addition of bioactive compounds was used as control.

The color was determined using colorimeter Minolta (CR410), operating in the CIE system $\left(\mathrm{L}^{*}, \mathrm{a}^{*}, \mathrm{~b}^{*}\right)$. Moisture was determined by infrared scale (Marte ID200, Marconi) using $3 \mathrm{~g}$ of sample at a temperature of 105 ${ }^{\circ} \mathrm{C}$ until constant weight. Water activity was determined by water activity analyzer (Novasina, LabTouch-aw) at temperature of 25 ${ }^{\circ} \mathrm{C}$. Acidity was determined by titration using a $1 \mathrm{M}$ sodium hydroxide solution according to the procedures of the Normative Instructions of December 12, 2006 (Brazil, 2006). Viscosity was determined by viscometer (Brookfield DV - III + Rheometer) using cylindrical spindle (SC4-25) at $40{ }^{\circ} \mathrm{C}$. $\mathrm{pH}$ was determined using benchtop pHmeter (Digimed, DM20) by direct reading from the diluted sample.

\section{Antioxidant Activity and Phenolic Compounds Content}

In order to determine the antioxidant activity and the phenolic compounds content, the chocolate samples were degreased, in which $10 \mathrm{~mL}$ of hexane were added in $2 \mathrm{~g}$ of samples and submitted to ultrasound for 2 minutes. Then, the mixture was centrifuged (5000 RPM, $25^{\circ} \mathrm{C}, 10$ minutes) and the supernatant was discarded. The procedure was performed twice, so the remaining solvent evaporated from the degreased sample. After that, a second extraction was performed using $10 \mathrm{~mL}$ of an acetone:water:acetic acid extraction solution (70:29.5:0.5). The sample was homogenized, centrifuged twice and the supernatant was collected in a $50 \mathrm{~mL}$ flask in where the volume with the extraction solution was completed (BATTISTON et al., 2016).

The antioxidant activity was determined by the DPPH (2,2-diphenyl-1-picrylhidrazyl) free radical capture method, described by Brand-Williams, Cuvelier \& Berset (1995). $1 \mathrm{~mL}$ of the degreased chocolate sample extract at different concentrations ( 0.0025 to 10 $\mathrm{mg} / \mathrm{mL}$ ) and $1 \mathrm{~mL}$ of $0.1 \mathrm{mM}$ DPPH ethanol solution were added to a test tube. The tubes were incubated in absence of light for $30 \mathrm{mi}-$ nutes, then read at $515 \mathrm{~nm}$ spectrophotometer. The Antioxidant activity was calculated by linear regression and expressed as $\mathrm{IC}_{50}(\mathrm{mg} /$ $\mathrm{mL}$ ), which is the concentration necessary to inhibit $50 \%$ of the free radical DPPH.

The total phenolic compounds content was determined by Folin-Ciocalteau method, using galic acid as a standard reference, described by Singleton, Othofer \& Lamuela-Raventos (1999) with adaptations. $1 \mathrm{~mL}$ of the degreased chocolate extract, $0.5 \mathrm{~mL}$ of Folin-Ciocalteau reagent, $2 \mathrm{~mL}$ of $20 \%(\mathrm{~m} / \mathrm{v})$ sodium carbonate and $2.5 \mathrm{~mL}$ of water were added to a test tube. The tubes were shaken and stored in the absence of light for $10 \mathrm{mi}-$ 
nutes and then read at a spectrophotometer at $760 \mathrm{~nm}$. The phenolic compounds content was calculated from a standard gallic acid curve and expressed as gallic acid equivalents per gram (mg GAE/g).

\section{Statistical analysis}

The results were statistically treated by analysis of variance (ANOVA), followed by the comparison of average differences by the Tukey's test, with a 95\% confidence level, using the Statistica 7.0 (StatSoft, Tulsa, EUA) software.

\section{Results and discussion}

Six formulations of different types of chocolate were made. Figure 1 shows the visual appearance of bitter, white and milk chocolate without, with added blueberry by-product and mint extract. Bitter and milk types had little variation in visual appearance, while white chocolate presented a difference in color, tending to purple for the blueberry by-product added sample.

Table I presents the results of color, moisture, water activity, acidity, viscosity and $\mathrm{pH}$ physicochemical analysis of the bitter, white and milk chocolate samples, with and without the addition of blueberry by-product and mint extract.

Regarding the color analysis parameter $\mathrm{L}^{*}$ refers to the luminosity, that comprises a range from 0 to 100 corresponding from the black to white. The parameters $a^{*}$ and $b^{*}$ are coordinates responsible for the chromaticity where $a^{*}$ positive values characterize the color red, negative the color green $\left(-\mathrm{a}^{*}\right), \mathrm{b}^{*}$ positive the color yellow and negative the color blue $\left(-b^{*}\right)$.

Bitter chocolate is naturally darker than the other types and showed the lowest $\mathrm{L}^{*}$ values (30.54 to 33.09), with no significant difference when blueberry by-product and mint extract were added. For white chocolate,

Figure 1 - Visual aspect of bitter, white and milk chocolate without additive (a, b, c); with added blueberry (d, e, f); and with added $\operatorname{mint}(\mathrm{g}, \mathrm{h}, \mathrm{i})$, respectively

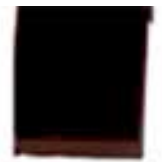

(a)

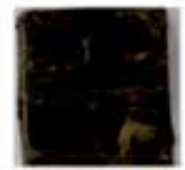

(d)

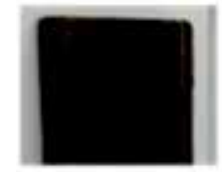

(g)

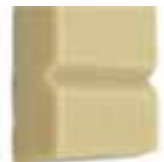

(b)

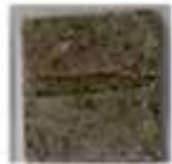

(e)

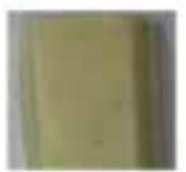

(h)

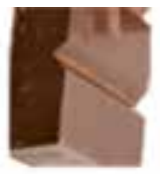

(c)

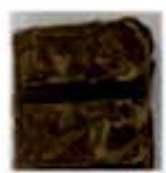

(f)

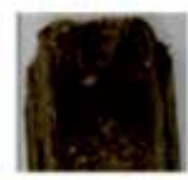

(i) 
the $\mathrm{L}^{*}$ values of 91.11 of the control sample and 91.02 of the sample added with mint extract, indicate the predominant white color, while the addition of blueberry by-product showed a significant difference from the others, reducing the value of $L^{*}$ (64.52) due to the characteristic pigments of the blueberry. Likewise, the $L^{*}$ values for milk chocolate added with blueberry by-product (35.93) showed a significant difference from the sample added with mint extract (40.62), but both did not show any significant difference in relation to the control sample (38.25).

The parameter $\mathrm{a}^{*}$, corresponding to the red color, for bitter chocolate showed an increase for the sample added with blueberry and mint extract (11.25 and 10.17, respectively). For white chocolate, the addition of mint extract (-3.13) did not show a significant difference from the control sample (-3.12) for a*. There was no visual difference in the color of white chocolate added with mint extract, as it can be seen in Figure 1 (h), possibly because the amount of extract added is very small.

For parameter $b^{*}$, all chocolate samples with the addition of blueberry by-product showed a significant reduction in relation to the control, with white chocolate having the lower index (5.86). The addition of mint extract caused little variation by reducing the $\mathrm{b}^{*}$ value for bitter (9.00) and white (20.60) chocolate and increasing for milk chocolate (17.66) in relation to their respective controls.

In general, white chocolate has in its composition substances that highlight the color, so it suffered the greatest variations. According to Teixeira (2009), the consumer's first contact with a product is usually visual, so color and appearance are important attributes that influence acceptance or rejection.

The moisture of the developed bitter chocolate formulations showed no significant difference among them, with levels from 0.2 to $0.25 \%$. For white and milk chocolate, the addition of blueberry by-product and mint extract showed a reduction in moisture content from 0.45 to 0.2 and $0.2 \%$ (white chocolate) and from 1.15 to 0.6 and $0.27 \%$ (milk chocolate), respectively. All the moisture contents mentioned are according to the Brazilian legislation that allows a maximum of $3 \%$ humidity in chocolate (BRASIL, 2005). The moisture content of chocolate bars depends, directly, on the moisture of the ingredients, processing and the shelf life of the product. The expected humidity for roofing chocolate produced with cocoa butter is between 1.0 and $1.5 \%$ (LANNES, 1997). Moreover, differences in levels of moisture content of the chocolate may have been influenced directly by the different relative humidity values of the air, of the processing environment and over the days the chocolate was produced (LUCCAS, 2001).

The control samples of bitter, white and milk chocolate showed water activity values of $0.44,0.38$ and 0.39 , respectively. The formulation containing blueberry by-product and mint extract showed an increase in water activity, and for bitter and white chocolate the Tukey test indicated a significant difference from the control sample. According to Efraim (2009), water activity results are in a range of water activity in which few deterioration reactions can occur, indicating their chemical and physical stability, if stored in adequate conditions of humidity and temperature.

A significant reduction $(\mathrm{p}<0.05)$ in the acidity of bitter chocolate (158.54 meq $\mathrm{NaOH} / 100 \mathrm{~g}$ ) was observed when adding blueberry by-product (132.78 meq $\mathrm{NaOH} / 100 \mathrm{~g})$ and mint extract $(141.20 \mathrm{meq}$ $\mathrm{NaOH} / 100 \mathrm{~g}$ ) in the formulation. White chocolate formulations showed no significant difference $(p>0.05)$ for acidity. Milk chocolate had a reduction in acidity of $179.27 \mathrm{meq}$ $\mathrm{NaOH} / 100 \mathrm{~g}$ of the control sample to 113.95 and 105.69 meq $\mathrm{NaOH} / 100 \mathrm{~g}$ for samples containing blueberry by-product and mint 


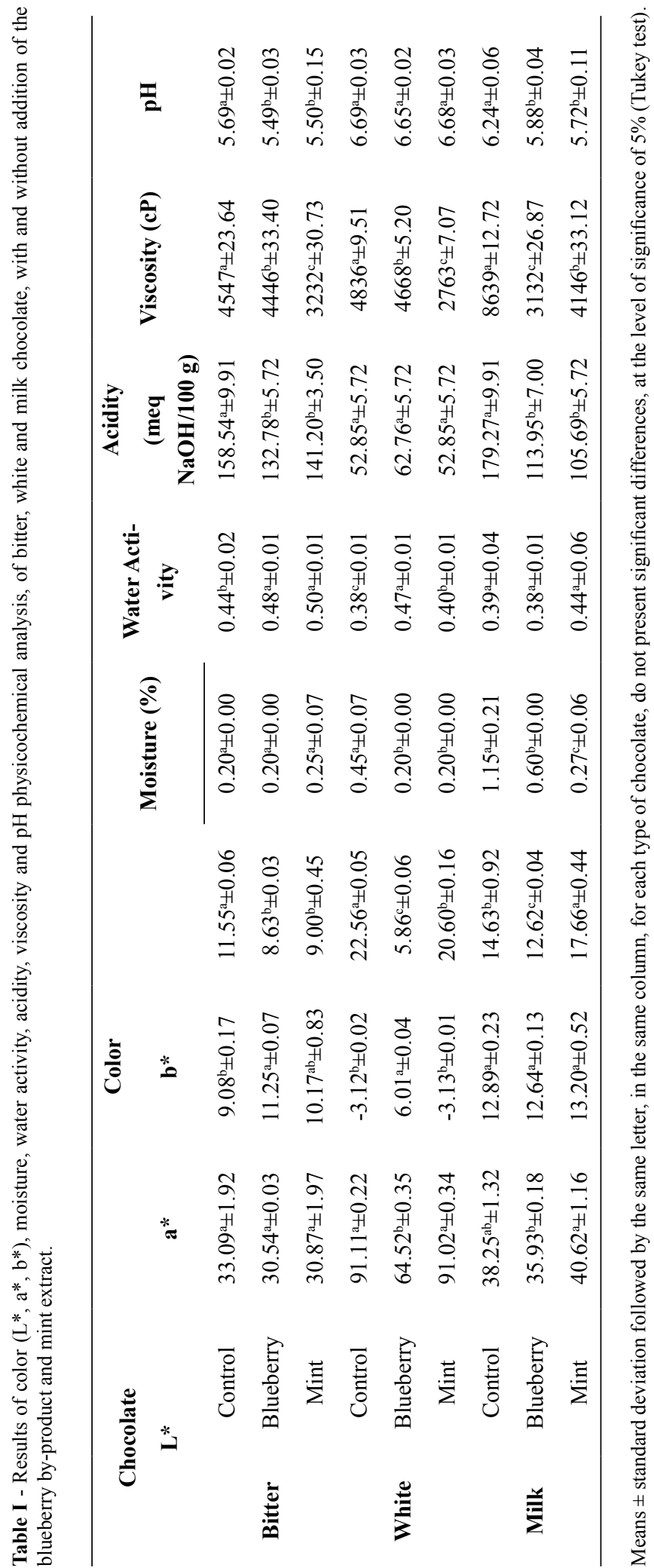


extract, respectively. These results are related to the $\mathrm{pH}$ values observed for chocolate, the white one did not present significant difference, while the bitter and the milk showed a reduction in the $\mathrm{pH}$ when added blueberry by-product and mint extract. For bitter chocolate added with blueberry by-product the $\mathrm{pH}$ decreased from 5.69 to 5.49 , while milk chocolate reduced from 6.24 to 5.88 with the addition of blueberry by-product and to 5.72 with the addition of mint extract.

The addition of blueberry by-product and mint extract caused a reduction in viscosity in the chocolate samples, in which all types showed significant differences. According to Efraim (2009), the factors that may influence chocolate rheological properties are temperature analysis, lipids content (cocoa butter), the size of the solid particles and moisture content, given that an increase in the content of humidity from 1.0 to $2.9 \%$ can lead to a $200 \%$ viscosity increase.

The highest viscosity value found was $8639 \mathrm{cP}$ for the milk chocolate control sample, which is in accordance to the highest moisture content $(1.15 \%)$ observed. The samples showed viscosity according to what is recommended in the literature, in which values between 1 to $20 \mathrm{~Pa}$.s, that is, 1000 to $20000 \mathrm{cP}$ for chocolate (BATISTON et al., 2016). In addition, the reduction in viscosity observed with the reduction in the moisture content of chocolate when added blueberry by-product and mint extract, except the bitter, suggest the iteration of moisture with these ingredients, as they undergo a drying stage and are highly hydrophilic.

Table II shows the antioxidant activity and phenolic compounds content of bitter, white and milk chocolate, with and without the addition of blueberry by-product and mint extract. According to the $\mathrm{IC}_{50}$ results, it can be seen that both the addition of blueberry and the addition of mint extract did not significantly increase the $\mathrm{IC}_{50}$ indices. This may be due to the low concentration of blueberry and mint extract added to the chocolate. It was not possible to determine the antioxidant activity for white chocolate samples and for bitter chocolate added with blueberry by-product because the values were outside the analyzed concentration range. According to Titton et

Table II - Antioxidant activity and phenolic compounds content of the chocolates.

\begin{tabular}{|c|c|c|c|}
\hline \multicolumn{2}{|c|}{ Chocolate } & \multirow{2}{*}{$\begin{array}{c}\begin{array}{c}\mathrm{IC}_{\mathbf{5 0}} \\
(\mathbf{m g} / \mathbf{m L})\end{array} \\
0.68^{\mathrm{a}} \pm 0.04\end{array}$} & \multirow{2}{*}{$\begin{array}{c}\begin{array}{c}\text { Phenolic Compounds } \\
\text { (mg GAE/g) }\end{array} \\
0.85^{\mathrm{c}} \pm 0.04\end{array}$} \\
\hline & Control & & \\
\hline \multirow[t]{3}{*}{ Bitter } & Blueberry & $*$ & $1.42^{\mathrm{a}} \pm 0.06$ \\
\hline & Mint & $0.62^{\mathrm{a}} \pm 0.02$ & $1.26^{\mathrm{b}} \pm 0.01$ \\
\hline & Control & $*$ & $0.85^{\mathrm{a}} \pm 0.04$ \\
\hline \multirow[t]{3}{*}{ White } & Blueberry & $*$ & $0.86^{\mathrm{a}} \pm 0.03$ \\
\hline & Mint & $*$ & $0.88^{\mathrm{a}} \pm 0.03$ \\
\hline & Control & $3.85^{\mathrm{a}} \pm 0.24$ & $0.85^{b} \pm 0.03$ \\
\hline \multirow[t]{2}{*}{ Milk } & Blueberry & $4.12^{\mathrm{a}} \pm 1.15$ & $0.96^{\mathrm{a}} \pm 0.01$ \\
\hline & Mint & $4.50^{\mathrm{a}} \pm 0.57$ & $0.94^{\mathrm{a}} \pm 0.02$ \\
\hline
\end{tabular}

Means \pm standard deviation followed by the same letter, in the same column, for each type of chocolate, do not present significant differences, at the level of significance of $5 \%$ (Tukey test). * Values outside the analyzed concentration range. 
al. (2014) some substances found in food can inhibit the antioxidant activity of phenolic compounds, such as the amount of sugar.

As to phenolic compounds content, it is possible to observe in Table II that the addition of blueberry by-product and mint extract increased the concentration of this class of compounds in the chocolate. For bitter chocolate, the content of phenolic compounds increased from $0.85 \mathrm{mgGAE} / \mathrm{g}$ to 1.42 and $1.26 \mathrm{mgGAE} / \mathrm{g}$ when added blueberry by-product and mint extract, respectively. In milk chocolate increased the content of phenolic compounds to 0.96 and $0.94 \mathrm{mgGAE} / \mathrm{g}$ when added blueberry by-product and mint extract, respectively, showing a significant difference from the control sample $(0.85$ mgGAE/g).

The use of industrial residues, as the by-product of the blueberry juice production used in this work, in obtaining bioactive compounds, is an alternative for the deve- lopment of functional food in addition to adding economic and nutritional value to the products. Besides that, the use of antioxidants in products containing lipids is one of the main ways to minimize rancidity, delay the formation of toxic products, maintain sensory and nutritional quality and increase the shelf life of food products (MAISUTHISAKUL; SUTTAJIT; PONGSAWATMANIT, 2007).

\section{Conclusion}

In this study, bitter, white and milk chocolate formulation was developed, with addition of mint and blueberry. The results showed that there was no increase in the antioxidant activity of the chocolate evaluated with addition of mint and blueberry in concentrations of 0.3 and $3 \%$. Therefore, higher concentrations are needed to improve chocolate functional properties.

\section{ACKNOWLEDGMENTS}

The authors thank the Conselho Nacional de Desenvolvimento Científico e Tecnológico (CNPq), Coordenação de Aperfeiçoamento de Pessoal de Nível Superior (CAPES - Finance code 001) and Research Support Foundation of Rio Grande do Sul (FAPERGS).

\section{REFERENCES}

ANDÚJAR, I.; RECIO, M. C.; GINER, R. M.; RÍOS, J. L. Cocoa polyphenols and their potential benefits for human health. Oxidative medicine and cellular longevity, p. 1-23, 2012.

BABOVA, O.; OCCHIPINTI, A.; CAPUZZO, A.; MAFFEI, M. E. Extraction of bilberry (Vaccinium myrtillus) antioxidants using supercritical/subcritical $\mathrm{CO}_{2}$ and ethanol as co-solvent. The Journal of Supercritical Fluids, v. 107, p. 358-363, 2016.

BAJAJ, S.; UROOJ, A.; PRABHASANKAR, P. Antioxidative properties of mint (Mentha spicata L.) and its application in biscuits. Current Research in Nutrition and Food Science Journal, v. 4, p. 209-216, 2016. 
BATTISTON, C. S. Z.; DALLA ROSA, C.; BARRO, N. P. R.; MIGNONI, M. L. Caracterização físico-química e atividade antioxidante de chocolate branco com extrato de erva-mate. Revista Virtual de Química, v. 8, p. 1878-1888, 2016.

BRAND-WILLIAMS, W.; CULIVER M.E.; BERSET, C. Use of a free radical method to evaluate antioxidant activity. LWT - Food Science and Technology, v. 28, p. 25-30, 1995.

BRASIL. Ministério da Saúde. Agência Nacional de Vigilância Sanitária. Resolução RDC n.264, de 22 de setembro de 2005. Aprova Regulamento Técnico para Fixação de Identidade e Qualidade de Chocolate e Chocolate Branco. Disponível em: http://elegis.anvisa.gov.br/leisref/public/showAct. php?id $=18823 \&$ word $=$ chocolate.

BRAZIL. Ministry of Agriculture, Livestock and Supply. (2006). Normative Instruction No. 68, of December 12, 2006. Approves the official physical-chemical analytical methods for control of milk and dairy products. Diário Oficial da União. Brasília, DF, Dec. 12, 2006. Section 1, p. 8.

CARLSEN, H.; MYHRSTAD, M. C. W.; THORESEN, M.; MOSKAUG, J. Ø.; BLOMHOFF, R. Berry Intake Increases the Activity of the $\gamma$-Glutamylcysteine Synthetase Promoter in Transgenic Reporter Mice. The Journal of Nutrition, v. 133, p. 2137-2140, 2003.

ÇAM, M.; YÜKSEL, E.; ALAŞALVAR, H.; BAŞYIĞIT, B.; ŞEN, H.; YILMAZTEKIN, M.; SAĞDIÇ, O. Simultaneous extraction of phenolics and essential oil from peppermint by pressurized hot water extraction. Journal of Food Science and Technology, v. 56, p. 200-207, 2018.

DORDONI, R.; DUSERM GARRIDO, G.; MARINONI, L.; TORRI, L.; PIOCHI, M.; SPIGNO, G. Enrichment of Whole Wheat Cocoa Biscuits with Encapsulated Grape Skin Extract. International Journal of Food Science, 2019.

EFRAIM, P. Contribuição à melhoria de qualidade de produtos de cacau no Brasil, através da caracterização de derivados de cultivares resistentes à vassoura-de-bruxa e de sementes danificadas pelo fungo. Tese (Doutorado em Tecnologia de Alimentos) - Univesridade Estadual de Campinas, Campinas - SP, 2009. http://taurus.unicamp.br/bitstream/REPOSIP/255232/1/Efraim Priscilla_D.pdf

FISCHER, B.; RAUSCHKOLB, J. C.; CANSIAN, R. L.; FERNANDES, I. A.; JUNGES, A.; VALDUGA, E.; ZENI, J. Development of pasteurized coffee-flavored dairy beverage added with mint extract (Mentha x piperita). Acta Scientiarum. Technology, v. 42, e48474, 2020.

GUSTINELLI, G.; ELIASSON, L.; SVELANDER, C.; ALMINGER, M.; AHRNÉ, L. Supercritical $\mathrm{CO}_{2}$ extraction of bilberry (Vaccinium myrtillus L.) seed oil: Fatty acid composition and antioxidant activity. The Journal of Supercritical Fluids, v. 135, p. 91-97, 2018.

JAHANGIR, M. A.; SHEHZAD, A.; BUTT, M. S.; BASHIR, S. Influence of supercritical fluid extract of Cinnamomum zeylanicum bark on physical, bioactive and sensory properties of innovative cinnamaldehyde-enriched chocolates. Czech Journal of Food Sciences, v. 36, p. 28-36, 2018.

JASTER, H.; AREND, G. D.; REZZADORI, K.; CHAVES, V. C.; REGINATTO, F. H.; PETRUS, J. C. C. Enhancement of antioxidant activity and physicochemical properties of yogurt enriched with concentrated strawberry pulp obtained by block freeze concentration. Food Research International, v. 104, p. 119-125, 2018.

JOZINOVIĆ, A.; PANAK BALENTIĆ, J.; AČKAR, Đ.; BABIĆ, J.; PAJIN, B.; MILIČEVIĆ, B.; ŠUBARIĆ, D. Cocoa husk application in the enrichment of extruded snack products. Journal of food processing and preservation, v. 43, 2019.

KWON, H. C.; BAE, H.; SEO, H. G.; HAN, S. G. Chia seed extract enhances physiochemical and antioxidant properties of yogurt. Journal of Dairy Science, v. 102, p. 4870-4876, 2019.

LANNES, S. C. da S. Estudo das propriedades físico-químicas e de textura de chocolates. 1997. Tese 
(Doutorado em Tecnologia de Alimentos) - Faculdade de Ciências Farmacêuticas, Universidade de São Paulo, São Paulo, 1997.

LONČAREVIĆ, I.; PAJIN, B.; FIŠTEŠ, A.; ŠAPONJAC, V. T.; PETROVIĆ, J.; JOVANOVIĆ, P.; ZARIĆ, D. Enrichment of white chocolate with blackberry juice encapsulate: Impact on physical properties, sensory characteristics and polyphenol content. LWT - Food Science and Technology, v. 92, p. 458-464, 2018.

LONČAREVIĆ, I.; PAJIN, B.; TUMBAS ŠAPONJAC, V.; PETROVIĆ, J.; VULIĆ, J.; FIŠTEŠ, A.; JOVANOVIĆ, P. Physical, sensorial and bioactive characteristics of white chocolate with encapsulated green tea extract. Journal of the Science of Food and Agriculture, 2019.

LUCCAS, V.; BONOMI, É. C.; KIECKBUSCH, T. G. Comparative characterization between milk chocolates formulated with anhydrous milk fat and with milk fat stearin. Brazilian Journal of Food Technology, v. 17, n. 2, p. 130-138, 2014.

MACHIANI, M. A.; JAVANMARD, A.; MORSHEDLOO, M. R.; MAGGI, F. Evaluation of yield, essential oil content and compositions of peppermint (Mentha piperita L.) intercropped with faba bean (Vicia faba L.). Journal of Cleaner Production, v. 171, p. 529-537, 2018.

MADANE, P.; DAS, A. K.; PATEIRO, M.; NANDA, P. K.; BANDYOPADHYAY, S.; JAGTAP, P.; LORENZO, J. M. Drumstick (Moringa oleifera) flower as an antioxidant dietary fibre in chicken meat nuggets. Foods, v. 8, 2019.

MAISUTHISAKUL, P.; SUTTAJIT, M.; PONGSAWATMANIT, R. Assessment of phenolic content and free radical-scavenging capacity of some Thai indigenous plants. Food Chemistry, v. 100, p. 1409-1418, 2007.

MIKULIC-PETKOVSEK, M.; SCHMITZER, V.; SLATNAR, A.; STAMPAR, F.; VEBERIC, R. A comparison of fruit quality parameters of wild bilberry (Vaccinium myrtillus L.) growing at different locations. Journal of the Science of Food and Agriculture, v. 5, p. 776-785, 2015.

MOO-HUCHIN, V. M.; MOO-HUCHIN, M. I.; ESTRADA-LEÓN, R. J.; CUEVAS-GLORY, L.; ESTRADA-MOTA, I. A.; ORTIZ-VÁZQUEZ, E.; SAURI-DUCH, E. Antioxidant compounds, antioxidant activity and phenolic content in peel from three tropical fruits from Yucatan, Mexico. Food Chemistry, v. 166, p. 17-22, 2015.

MUDENUTI, N. V. de R.; de CAMARGO, A. C.; SHAHIDI, F.; MADEIRA, T. B.; HIROOKA, E. Y.; GROSSMANN, M. V. E. Soluble and insoluble-bound fractions of phenolics and alkaloids and their antioxidant activities in raw and traditional chocolate: A comparative study. Journal of Functional Foods, v. 50, p. 164-171, 2018.

MUHAMMAD, D. R. A.; SAPUTRO, A. D.; ROTTIERS, H.; VAN DE WALLE, D.; DEWETTINCK, K. Physicochemical properties and antioxidant activities of chocolates enriched with engineered cinnamon nanoparticles. European Food Research and Technology, v. 244, p. 1185-1202, 2018.

PAPILLO, V. A.; LOCATELLI, M.; TRAVAGLIA, F.; BORDIGA, M.; GARINO, C.; COÏSSON, J. D.; ARLORIO, M. Cocoa hulls polyphenols stabilized by microencapsulation as functional ingredient for bakery applications. Food Research International, v. 115, p. 511-518, 2019.

RAMAR M.; MANIKANDAN B.; RAMAN T.; ARUNAGIRINATHAN K.; PRABHU N. M.; BASU M. J.; PERUMAL M.; PALANISAMY S.; MUNUSAMY A. Biosynthesis of silver nanoparticles using ethanolic petals extract of Rosa indica and characterization of its antibacterial, anticâncer and antiinflammatory activities. Spectrochimica Acta Part A: Molecular and Biomolecular Spectroscopy, v. 138, p. 120-129, 2015.

SARAIVA, B. R.; VITAL, A. C. P.; ANJO, F. A.; RIBAS, J. C. R.; PINTRO, P. T. M. Effect of yerba mate (Ilex paraguariensis A. St.-Hil.) addition on the functional and technological characteristics of 
fresh cheese. Journal of Food Science and Technology, v. 56, p. 1256-1265, 2019.

SHAHAMIRIAN, M.; ESKANDARI, M. H.; NIAKOUSARI, M.; ESTEGHLAL, S.; GAHRUIE, H. H.; KHANEGHAH, A. M. Incorporation of pomegranate rind powder extract and pomegranate juice into frozen burgers: oxidative stability, sensorial and microbiological characteristics. Journal of Food Science and Technology, v. 56, p. 1174-1183, 2019.

SINGLETON, V. L.; ORTHOFER, R.; LAMUELA-RAVENTÓS, R. M. Analysis of total phenols and other oxidation substrates and antioxidants by means of folin-ciocalteau reagente. Methods in Enzymology, v. 229, p. 152-178, 1999.

TEIXEIRA, L. V. Análise sensorial na indústria de alimentos. Revista do Instituto de Laticínios “Cândido Tostes", v. 64, p. 12-21, 2009.

TITTON, N. F.; SCHUMACHER, A. B.; DANI, C. Estudo comparativo da quantidade de polifenóis totais e da atividade antioxidante em diferentes chocolates: ao leite, meio amargo, amargo e de soja. Ciência em Movimento, v. 16, p. 77-84, 2014.

VANDERSCHUEREN, R.; MONTALVO, D.; DE KETELAERE, B.; DELCOUR, J. A.;

SMOLDERS, E. The elemental composition of chocolates is related to cacao content and origin: A multi-element fingerprinting analysis of single origin chocolates. Journal of Food Composition and Analysis, v. 83, 2019. 